\title{
Penulisan Teks Prosedur Yang Dinilai Menggunakan Portofolio Kepada Mahasiswa Semester Empat Pada Jurusan Tata Boga di Politeknik Negeri Balikpapan
}

\author{
Abdul Gafur. (), Elisabeth Milaningrum ${ }^{2)}$ \\ Jurusan Tata Boga \\ Politeknik Negeri Balikpapan \\ Jl. Soekarno-Hatta Km 8 Balikpapan \\ abdul.gafur9@gmail.com
}

\begin{abstract}
The purposes of this study were (1) to know the structures of procedure text written by the third semester students of Culinary Department in the State Polytechnic of Balikpapan, (2) to know the students' development in writing the procedure text assessed through portfolio. The design of this study was a descriptive of qualitative design. The researcher involved 15 students from 28 Diploma Students of the third semester of Culinary Department of the State Polytechnic of Balikpapan in order to get their data or documents of procedure text writing results. The source data were taken from the writing results based on four topics given. The findings of this study showed that (1) there were four structures of procedure text written by the students, they were goal, ingredients/ materials, steps/ procedures, and evaluation, (2) there were any changes of the students' writing product after assessing through portfolio assessment developmentally. It can be compared from the students' writing between the first draft and the final draft for each topic given in which the aspects of writing process, organizational features, language features and clarity of writing found in the final draft have been stated and described effectively and meaningfully than the first draft written by the students. From the findings above, it can be implied that using portfolio assessment gave better result on the students' ability in writing the procedure text.
\end{abstract}

Keywords: Writing, Procedure Text, Portfolio

\section{Abstrak}

Tujuan dari penelitian ini adalah (1) untuk mengetahui struktur prosedur teks yang ditulis oleh mahasiswa semester ketiga Departemen Kuliner di Politeknik Negeri Balikpapan, (2) untuk mengetahui perkembangan mahasiswa dalam menulis teks prosedur yang dinilai melalui portofolio. Desain penelitian ini adalah deskriptif kualitatif. Peneliti melibatkan 15 mahasiswa dari 28 mahasiswa Diploma semester ketiga Program Studi Tata Boga di Politeknik Negeri Balikpapan untuk mendapatkan data atau dokumen dari hasil menulis teks prosedur mereka. Sumber data diambil dari hasil tulisan berdasarkan empat topik yang diberikan. Hasil dari penelitian ini menunjukkan bahwa (1) ada empat struktur prosedur teks yang ditulis oleh para mahasiswa, yaitu tujuan, bahan / material, langkah / prosedur, dan evaluasi, (2) ada perubahan dari produk menulis mahasiswa setelah menilai melalui penilaian portofolio perkembangan. Hal ini dapat dibandingkan dari menulis mahasiswa antara draft pertama dan draft akhir untuk setiap topik yang diberikan di mana aspek proses penulisan, fitur organisasi, fitur bahasa dan kejelasan tulisan yang ditemukan dalam draft akhir ini telah dinyatakan dan diuraikan secara efektif dan bermakna dari draft pertama ditulis oleh mahasiswa. Dari temuan di atas, dapat tersirat bahwa menggunakan penilaian portofolio memberi hasil yang lebih baik pada kemampuan siswa dalam menulis teks prosedur.

Kata Kunci : Menulis, Teks Prosedur, Portofolio. 


\section{Pendahuluan}

Belajar bahasa penting untuk perkembangan sosial, sebagai bahasa yang digunakan oleh lebih dari setengah populasi di dunia, bahasa Inggris, memainkan peran sebagai bahasa internasional. Bahasa Inggris adalah alat komunikasi antara orang-orang dari dunia untuk mencapai perdagangan, sosialbudaya, ilmu pengetahuan, dan teknologi gol. Selain itu, kompetensi bahasa Inggris penting dalam pengembangan karir. Oleh karena itu, mahasiswa perlu memahami dan menggunakan bahasa Inggris untuk meningkatkan kepercayaan diri mereka untuk menghadapi persaingan global.

Penelitian ini akan menyangkut kemampuan menulis dari mahasiswa semester keempat tata boga di Politeknik Negeri Balikpapan menulis karena peneliti sendiri memutuskan subjek English utama setiap semester tunggal. Dalam rangka memperkenalkan tes TOEFL untuk mahasiswa, ia membuat modul sendiri di TOEFL berbasis. Untuk semester pertama mereka akan diajarkan tentang keterampilan membaca pemahaman, pada semester keempat mahamahasiswa tata boga mereka mendapatkan kursus menulis pengantar yang hanya akan fokus dalam narasi dan esai deskriptif, pada semester berikutnya mereka akan mendapatkan keterampilan mendengarkan pemahaman dan kemampuan berbicara sebagai penutup dari setiap keterampilan bahasa Inggris mereka akan memiliki, untuk semester keempat dan kelima mereka tidak akan mendapatkan bahasa Inggris sebagai subjek mereka di kelas tetapi pada semester terakhir atau semester keenam mereka memiliki bahasa Inggris untuk profesi di mana pengenalan tes TOEFL juga akan dilakukan dalam semester.

Khusus untuk jurusan Tata Boga, mahamahasiswa tata boga semester keempat akan mendapatkan dasar bahasa Inggris untuk profesi. Dalam semester ini mahasiswa akan diajarkan tentang percakapan dan menulis teks prosedural tentang kegiatan restoran. Misalnya prosedur untuk membuat beberapa menu atau untuk menangani reservasi melalui telepon di restoran. Jadi, diharapkan mereka dapat juga berlaku kemampuan mereka di bidang restoran di kedua dalam Bahasa dan Inggris.

Berdasarkan kondisi secara tertulis saja semester keempat tata boga mahasiswa di politeknik Balikpapan, para peneliti akan menentukan teks prosedural untuk diberikan karena untuk menghubungkan kegiatan mereka di bidang restoran untuk pelajaran mereka di kelas mereka harus mampu untuk menjelaskan banyak hal tertib. Alasan yang memberikan pertimbangan juga untuk para peneliti sebagai dosen mereka yang bertanggung jawab untuk menerapkan penilaian portofolio. Seperti yang disebutkan di atas tentang penilaian portofolio bahwa mengukur tidak hanya untuk koleksi karya mahasiswa tetapi juga dapat menjadi monitor untuk mengontrol kemajuan pertumbuhan mahasiswa pengetahuan, keterampilan dan sikap di daerah konten yang spesifik. Penelitian ini akan fokus pada pengembangan kemampuan menulis mereka terutama teks prosedural digambarkan dari folder portofolio sebagai bukti fisik, sehingga mereka dapat merenungkan kesalahan mereka dibuat sebelumnya.

Memiliki pengalaman dalam proses penulisan adalah strategi yang baik untuk menghasilkan produk menulis yang efektif. Pemantauan dan menilai dari proses penulisan dapat berkontribusi untuk penguasaan mahasiswa dari keterampilan kemampuan menulis dan akhirnya kemahiran dalam menulis pada umumnya. Secara khusus, penelitian ini mencoba menjawab pertanyaan utama berikut:

- Bagaimana penulisan teks prosedural mahasiswa semester keempat mahamahasiswa tata boga di Politeknik Negeri Balikpapan dinilai melalui portofolio?

Pertanyaan ini bisa bercabang menjadi pertanyaan-pertanyaan berikut: 
1. Bagaimana perkembangan ide-ide yang akan diselenggarakan dalam teks prosedural?

2. Bagaimana perkembangan struktur yang akan diselenggarakan dalam teks prosedural?

Tujuan utama dari penelitian ini secara teoritis adalah untuk menyelidiki proses produk menulis teks prosedural dengan semester keempat mahasiswa tata boga mahasiswa Politeknik Negeri Balikpapan dinilai melalui penilaian portofolio. Para peneliti percaya bahwa konduksi penelitian dapat memberikan informasi berharga untuk pengembangan sistem portofolio sebagai sistem alternatif. Hasil dari penelitian ini akan sangat penting bagi dosen untuk meningkatkan kualitas proses pembelajaran terutama dalam kursus bahasa Inggris.

Menulis adalah kegiatan progresif. Ini berarti bahwa ketika penulis pertama menulis sesuatu, mereka sudah berpikir tentang apa yang akan dikatakan dan bagaimana akan mengatakan itu. Kemudian setelah menulis selesai, penulis membaca lebih apa yang telah ditulis dan membuat perubahan dan koreksi. Oleh karena itu, menulis adalah tidak pernah tindakan satu langkah; itu adalah proses yang memiliki beberapa langkah (Oshima dan Hogue, 1997).

\section{A. Definisi Teks Prosedur}

Ketika kita menulis teks prosedur apapun, kita harus menggabungkan akurasi detail dengan singkat dan ketertiban (Jolly, 1993). Tujuan dari teks prosedur adalah untuk menunjukkan bagaimana sesuatu dilakukan (Feez dan Joyce, 1998). Mereka juga menjelaskan bahwa teks prosedur menunjukkan bagaimana melaksanakan tindakan dalam urutan tertentu. Feez dan Joyce mengatakan bahwa teks prosedur harus memiliki tiga tahap. Yang pertama adalah tujuan yang menyatakan tujuan dan memprediksi kesimpulan kemungkinan. Yang kedua adalah bahan yang merupakan daftar alat atau peralatan yang dibutuhkan dan zat atau benda sedang diselidiki. Tahap terakhir adalah langkah-langkah yang merupakan tindakan, tercantum dalam urutan, yang diperlukan untuk menyelesaikan eksperimen atau prosedur. Setiap langkah yang tertulis pada baris terpisah dan setiap langkah ditulis sebagai perintah.

\section{B. Contoh Teks prosedur}

Teks Prosedur ini diadopsi dari Otong Setiawan Djuharie, GENRE, (2008), halaman. 39.

Tujuan: Cara Membuat Keju Omelet

Bahan: 1 butir telur, $50 \mathrm{~g}$ keju, susu cangkir, 3 sendok makan minyak goreng, garam dan merica.

Alat-alat: Penggorengan, garpu, spatula, parutan keju, mangkuk dan piring.

Langkah-langkah:

a) Pertama, retak telur ke dalam mangkuk

b) Kedua, mengocok telur dengan garpu sampai halus

c) Ketiga, tambahkan susu dan aduk dengan baik

d) Keempat, parut keju ke dalam mangkuk dan aduk

e) Kelima, panaskan minyak dalam wajan

f) Keenam, tuangkan campuran dalam wajan

g) Ketujuh, putar telur dadar dengan spatula ketika cokelat

h) Berikutnya, memasak kedua belah pihak

i) Kemudian tempat di piring; musim dengan garam dan merica.

j) Akhirnya, makan selagi hangat

Menurut Simon dan Forgette-Giroux pada Isabella (2008), portofolio adalah kumpulan kumulatif dan berkelanjutan dari entri yang dipilih mengikuti kerangka yang diberikan, dan direnungkan oleh mahasiswa, untuk menilai / pengembangan dirinya dari kompetensi tertentu tetapi kompleks . Demikian pula, portofolio juga dikenal sebagai catatan proses anak belajar yang menggambarkan gaya pelajar dari pemikiran, pertanyaan, analisis, produksi, pembuatan, dan sejenisnya (Grace, 2008). Umumnya berbicara, portofolio dapat 
dilihat sebagai kumpulan sistematis dan terorganisir bukti yang digunakan oleh guru dan mahasiswa untuk memantau pertumbuhan mahasiswa pengetahuan, keterampilan, dan sikap di daerah konten yang spesifik.

\section{Metoda Penelitian}

Mengacu pada judul penelitian ini, para peneliti merancang penelitian ini menjadi penelitian kualitatif. Penelitian ini diharapkan dapat menggambarkan, menjelaskan dan menunjukkan fenomena yang diselidiki dari produk penulisan mahasiswa dalam membuat teks prosedur dinilai melalui portofolio. Memiliki melihat pengawasan dan analisis, variabel diteliti terhadap mahamahasiswa semester IV jurusan tata boga di Politeknik Negeri Balikpapan telah disajikan dalam data kualitatif.

(1999) menyatakan bahwa tujuan penelitian deskriptif adalah untuk mengamati, menjelaskan, aspek dokumen situasi seperti itu terjadi secara alami.

Berdasarkan pernyataan di atas, para peneliti menyimpulkan bahwa penelitian deskriptif adalah penelitian untuk membuat gambaran mengenai situasi atau kejadian dengan mengumpulkan dan menggambarkan data secara detail. Sementara desain tesis ini adalah penelitian deskriptif yang diharapkan untuk menggambarkan, menjelaskan, dan menunjukkan fenomena yang diselidiki pada penggunaan penilaian portofolio dalam kursus menulis pengantar mahasiswa.

\section{Peserta}

Purposive sampling didefinisikan sebagai: 'pengambilan sampel Menghakimi yang melibatkan pemilihan sadar oleh peneliti dari subjek atau elemen-elemen tertentu untuk memasukkan dalam studi' (Crookes dan Davis 1998).

Penelitian ini akan menggunakan lima belas mahasiswa sebagai sampel. Mereka mahasiswa akan dipilih sebagai kemampuan mereka sendiri dalam menulis. Lima mahasiswa pertama memiliki skor tertinggi dari tulisan pra-tes, yang kedua lima mahasiswa memiliki kemampuan tengah menulis dan lima mahasiswa terakhir akan menjadi berprestasi rendah menulis. Pre-test akan diberikan dalam bentuk tulisan bebas, seluruh mahasiswa di kelas akan menulis bebas tentang kegiatan sehari-hari mereka selama sehari dan akan mencetak berdasarkan rubrik penilaian untuk penulisan diadaptasi dari Self, nd di O 'Malley dan Pierce (1996).

\section{Prosedur Penelitian}

Data yang dibutuhkan untuk penelitian ini adalah paragraf bahasa Inggris dalam bentuk teks prosedur. Data untuk penelitian ini dikumpulkan dengan menggunakan instrumen scoring analitik dan bentuk kertas portofolio. Bentuk portofolio seharusnya melihat kemajuan kemampuan menulis mereka dalam membuat tulisan teks prosedur.

Prosedur untuk mengumpulkan data dijelaskan dalam langkah-langkah berikut. Pertama, dosen pertama akan datang ke kelas dan memberikan beberapa aturan untuk mahasiswa apa yang akan mereka miliki selama semester. Dalam pertemuan itu dosen juga akan meminta mereka untuk melakukan penulisan bebas atau curah pendapat dengan memberikan tugas untuk menulis sebuah paragraf dengan topik bebas yang akan dipilih sendiri. Dalam bagian itu, dosen akan menyerahkan semua koleksi kerja dan melihat bagaimana kemampuan menulis mereka. Pengukuran akan berurusan dalam penguasaan kosakata, koherensi antara satu kalimat yang lain, dan kesatuan paragraf. Dengan demikian, setelah mengetahui kemampuan mereka dosen akan memutuskan apa yang akan menjadi topik lebih lanjut untuk diberikan sebagai tugas dan evaluasi selama semester. Pada bagian ini, dosen juga akan meminta para mahasiswa untuk memiliki folder hijau yang terdiri dari 25 lembar kertas. Bentuk lembaran kertas telah diputuskan oleh dosen dalam rangka untuk 
menggeneralisasi format mahasiswa seluruh 'catatan, dan juga untuk membuat mereka mencerminkan kemajuan mereka sendiri dalam menulis produk.

Kedua, dalam pertemuan berikutnya, dosen akan memberikan tugas "bagaimana membuat makanan penutup Indonesia" topik. Mahasiswa akan diminta untuk memilih apa gurun akan memutuskan untuk menulis. Mereka mungkin tidak memungkinkan melihat terjemahan melalui google translate atau kamus ponsel, alat yang mereka dapat membawa hanya kamus elektronik atau kamus kontemporer. Semua tugas yang harus dilakukan oleh kemampuan mereka sendiri atau meminta dosen jika memenuhi beberapa kendala dalam menerjemahkan kegiatan. Setelah selesai memutuskan menu, mereka mungkin membuat tulisan bebas mereka tentang daftar bahan dan peralatan untuk membuat menu mereka telah memutuskan. Setelah itu mereka diminta untuk membuat daftar langkah dalam urutan acak selama mereka bisa menghafal langkah sebelumnya. Kegiatan selanjutnya adalah meminta mereka untuk dimasukkan ke dalam tabel teks prosedur menu dalam rangka. Ini akan dimulai dari tujuan, bahan dan akan diakhiri dengan langkah-langkah yang teratur. Kemudian pada akhir pertemuan mereka harus menyampaikannya kepada dosen yang akan diperbaiki dan berkomentar di pertemuan berikutnya sebagai refleksi dari produk tulisan mereka.

Ketiga, setelah pengenalan teks prosedur dalam pertemuan sebelumnya, dosen akan meminta mereka tentang apa yang telah mereka lakukan minggu lalu, dan meminta mereka apakah mereka masih ingat setiap detail dari pertemuan tersebut. Bagian ini memberikan gambar untuk mengetahui apakah mahasiswa masih sadar atau tidak dalam pertemuan sebelumnya. Kegiatan selanjutnya adalah memberikan mahasiswa beberapa langkah bagaimana membuat prosedur yang baik menulis dengan topik "Bagaimana Menangani Reservation Selama Telepon".
Mereka harus membuat beberapa daftar apa yang akan terjadi selama reservasi melalui telepon, setelah itu mereka membuat pra menulis dari daftar termasuk mempersiapkan tujuan dan bahan harus digunakan, dan langkah berikutnya adalah mereka harus memesan pre tulisan mereka ke dalam beberapa langkah yang baik dan terstruktur, maka mereka harus membuat draft pertama dari garis mereka sendiri yang telah dilakukan sebelumnya. Langkah-langkah di atas dilakukan oleh mahasiswa disampaikan kepada dosen dan dikoreksi juga berkomentar apa yang harus mereka lakukan dalam menyempurnakan produk tulisan mereka, setelah kembali draft pertama mereka dengan beberapa koreksi mereka harus membuat rancangan akhir yang harus dilakukan dalam pertemuan berikutnya.

Keempat, selama pertemuan ketiga mereka telah dilakukan dengan baik, dosen maka akan memberikan topik "Cara Bersihkan Meja". Para mahasiswa akan diperintahkan untuk apa yang harus diletakkan di atas meja restoran yang bagus, dan mereka harus daftar peralatan yang diperlukan. Setelah itu mereka akan diminta untuk membuat langkah-langkah bagaimana untuk membersihkan meja setelah bahan yang digunakan dan apa yang digunakan untuk membersihkan meja kotor.

Kelima, evaluasi atau disebut Kuis akan diadakan dalam pertemuan ini, para mahasiswa akan diberikan topik "Bagaimana Menangani Keluhan" dan mereka harus menyelesaikan paragraf hanya 60 menit. Langkah-langkah yang harus mereka lakukan akan sama seperti langkah-langkah seperti apa yang sudah mereka lakukan pada awal prosedur menulis teks, dari membuat pra-menulis seperti tujuan prosedur, menentukan peralatan atau bahan, sampai membuat langkah yang teratur. Kuis ini juga disampaikan dan berkomentar dengan dosen dan akan memberikan kembali tugas kepada mereka untuk membuat koreksi 
dan memiliki draft akhir pada pertemuan berikutnya.

\section{Teknik Analisis Data}

Data dari penelitian ini akan dianalisis melalui prosedur analisis isi. Analisis isi adalah teknik penelitian untuk menganalisis secara sistematis komunikasi tertulis. Ini telah digunakan untuk mempelajari buku-buku, esai, artikel berita, pidato, pamflet dan bahan tertulis lainnya. Analisis isi dapat membantu mengidentifikasi propaganda atau menggambarkan sikap dan keadaan psikologis. Meskipun namanya, analisis isi lebih dari teknik reduksi data dari satu analitis karena itu rusak bahan teks panjang menjadi unit-unit yang lebih mudah dikelola data (Hall, 2013).

Analisis isi sesuai dalam penelitian ini karena menggambarkan karakteristik konten dan memiliki kesimpulan tentang penyebab konten dan efek konten. Teknik ini akan digunakan untuk menganalisis kualitas narasi dan teks deskriptif mahasiswa.

Ada lima langkah prosedur untuk menganalisis bahan teks atau data dari penelitian ini (Hall, 2013) yang akan di bawah yang menceritakan.

Langkah pertama adalah peneliti hanya akan fokus dalam pikiran dari pertanyaan penelitian yang telah dilakukan. Fokus pada penelitian ini hanya akan memilah dari pengembangan ide dan struktur, langkah-langkah fokus dan juga detail dari produk menulis mahasiswa.

Langkah kedua akan membiarkan para peneliti memilih peserta. Seperti yang telah dinyatakan sebelumnya bahwa peserta dalam penelitian ini akan hanya lima belas mahasiswa yang dibagi dari kemampuan mereka dalam menulis yang telah diuji di awal pertemuan.

Langkah ketiga adalah membaca dan mengkaji data. Sementara draft pertama dan draft akhir mahasiswa adalah di tangan, para peneliti kembali akan membaca dan meninjau produk-produk menulis dalam rangka untuk menyoroti dan fokus titik yang akan dicapai dalam penelitian ini.

Langkah keempat adalah mendefinisikan unit analisis dan kategori. Unit analisis dari data berdasarkan kode skor indikator dalam teks prosedur. Unit analisis data dalam ayat narasi akan berisi konten, gaya, kalimat pembentukan, penggunaan dan mekanik. Serupa dengan narasi, unit analisis dari data pada ayat deskriptif akan berisi konten, struktur detail, pembentukan kalimat, penggunaan, dan mekanik.

Unit kategori dalam penelitian ini juga didasarkan pada skor analitik sebagai scoring indikator untuk kedua paragraf perbedaan dari unit analisis adalah unit ini menggunakan pengkodean nomor sebagai nilai prestasi untuk setiap konten. Pencapaian tertinggi akan mendapatkan 4 (empat) nilai dan yang terendah akan mendapatkan 1 (satu) nilai mark. Setelah itu para peneliti akan mengisi tabel perbandingan setelah draft pertama dan draft akhir yang punya. Para peneliti akan menjelaskan secara singkat dalam tabel tentang perbedaan antara draft pertama dan draft akhir dibuat oleh mahasiswa, akan perhatian pada peningkatan mahasiswa produk menulis karena penelitian ini menggunakan penilaian portofolio untuk melihat semakin meningkatnya kualitas mahasiswa produk menulis .

Langkah kelima dalam penelitian ini menafsirkan dan melaporkan temuan. Apa yang akan para peneliti mendapatkan yang berasal dari unit analisis dan kategori yang akan dijelaskan berdasarkan temuan setiap produk dari tulisan dari peserta dalam penelitian ini.

\section{Hasil Penelitian}

Hasil dari penelitian ini ditemukan dari hasil menulis mahasiswa pada teks prosedur. Peneliti meminta 15 mahasiswa untuk menulis teks prosedur berdasarkan topik yang diberikan dalam setiap pertemuan. Para mahasiswa ditugaskan untuk menulis teks prosedur empat topik. Setiap topik, mahasiswa yang diajukan dua 
hasil tulisan yang berisi tentang draft pertama dan draft akhir. Draft pertama mengacu hasil tulisan mahasiswa berdasarkan kemampuan dan pengetahuan dalam menulis teks prosedur untuk pertama kalinya untuk setiap topik yang diberikan mereka; sedangkan draft akhir mengacu hasil tulisan mahasiswa yang telah dinilai oleh peneliti sebagai dosen mereka. Penilaian yang digunakan dalam penelitian ini adalah penilaian portofolio. Dalam hal ini, peneliti ingin mengetahui apakah penggunaan portofolio akan mengembangkan pengetahuan mahasiswa dalam menulis teks prosedur atau tidak.

Setelah meminta mahasiswa untuk menulis teks prosedur, kemudian memberikan umpan balik atau menilai produk tulisan mereka melalui portofolio, sebagian besar mahasiswa telah ditulis teks prosedur berdasarkan struktur yang baik dari teks prosedur. Ini berarti bahwa setiap teks prosedur yang ditulis oleh para mahasiswa telah menemukan struktur yang terdiri dari tujuan, bahan, langkah-langkah dan evaluasi. Meskipun ada 4 mahasiswa dari 15 mahasiswa yang masih lupa untuk mengevaluasi tulisan mereka atau struktur evaluasi teks prosedur yang tidak disebutkan pada tulisan mahasiswa.

Pada dasarnya, telah menyatakan bahwa mahasiswa diminta untuk menulis teks prosedur berdasarkan topik tertentu yang terdiri dari empat topik. Topik pertama dibahas tentang "pencuci mulut Indonesia", diikuti dengan "Penanganan reservasi melalui telepon", kemudian "Clear up meja", dan akhirnya "Penanganan keluhan". Setiap topik terdiri dari dua dokumen dari hasil tulisan yang disampaikan kepada peneliti di mana mereka dapat dibagi menjadi draft pertama dan draft akhir.

\section{Pembahasan}

Sehubungan dengan tujuan penulisan, Oshima dan Hogue (1997) menyatakan bahwa ada tiga bagian secara tertulis yang harus diketahui oleh penulis. Mereka penonton, nada, dan tujuan penulisan. Selanjutnya, mereka menjelaskan bahwa penonton mengacu penulis harus tahu siapa yang akan membaca nya / nya menulis, penawaran nada dengan gaya atau cara mengekspresikan ide, dan tujuan mengacu mengetahui bentuk retoris atau bentuk organisasi dan gaya penulisan. Melihat pernyataan di atas, dapat dikatakan bahwa mahasiswa dari studi ini telah dikenal pembaca mereka di mana pembaca yang pengusaha atau orang-orang yang selalu melakukan pelayanan hospitality atau orang-orang yang menerima layanan yang diberikan oleh staf. Jadi, mereka menulis dan menyatakan ide dalam menulis teks prosedur tertib, komunikatif dan ramah. Hal ini dapat dilihat dari struktur langkah yang ditulis oleh mahasiswa antara bagaimana membuat Dessert Indonesia, penanganan pemesanan melalui telepon, membersihkan meja, dan penanganan keluhan tamu. Langkah-langkah melakukan kegiatan tersebut digambarkan dengan jelas agar pembaca mereka dapat bertindak dengan mengikuti prosedur yang telah disampaikan. Meskipun, itu juga menemukan beberapa mahasiswa yang tidak dinyatakan prosedur lebih rinci tapi setelah memberikan portofolio, mereka telah direvisi dan menulis tulisan mereka tertib dan sistematis.

Penulisan dimengerti prosedur teks yang ditulis oleh para mahasiswa di atas didukung dengan menyatakan struktur prosedur teks yang dibuat oleh mahasiswa. Hal ini dapat menunjukkan bahwa mahasiswa menyatakan struktur tujuan untuk memperkenalkan apa yang mahasiswa untuk menulis, daftar bahan yang akan digunakan dalam membuat atau penanganan sesuatu yang harus disiapkan, tawaran langkah struktur dengan cara melakukan sesuatu yang telah direncanakan, dan struktur penawaran evaluasi dengan mengevaluasi apa yang telah dilakukan. Dalam hal ini, beberapa ahli sepakat untuk membagi struktur prosedur teks ke dalam beberapa tahapan; mereka Tujuan / judul / tujuan, bahan / material, langkah / metode / prosedur, dan 
kesimpulan / evaluasi (Feez dan Joyce, 1998; Derewianka, 2004). Mereka struktur teks prosedur yang ditemukan pada hasil tulisan mahasiswa.

Melihat struktur yang dinyatakan pada hasil tulisan mahasiswa, peneliti berasumsi bahwa mahasiswa akrab dengan topik yang diberikan sehingga mereka hanya ditransfer ide mereka dalam bentuk tertulis dan diterjemahkan dalam bahasa Inggris. Hal ini karena topik yang diberikan terkait dengan departemen mereka yang Departemen Tata boga. Dalam hal ini, Derewianka (2004) menunjukkan bahwa teks prosedur sudah akrab dengan kehidupan masyarakat, misalnya dalam memberikan petunjuk untuk membuat sesuatu, dalam aturan permainan, di resep, langkah manual, dan arah tujuan. Sudah jelas bahwa dengan topik yang sesuai diberikan kepada mahasiswa Jurusan Tata boga, itu akan lebih mudah bagi mereka untuk menulis apa yang mereka ingin menulis berdasarkan topik tertentu. Meskipun beberapa kesalahan dari fitur bahasa seperti tegang, bentuk kata kerja, perjanjian, artikel, dll dihiasi tulisan mereka karena dalam bahasa Indonesia, tidak menemukan tata bahasa atau tegang. Jadi, mahasiswa yang sulit untuk mengatur hukuman mereka sistematis dan tata bahasa.

Selain itu, telah dikatakan bahwa beberapa mahasiswa lupa untuk menyatakan struktur evaluasi tulisan mereka, peneliti berasumsi mengapa mereka tidak menulis struktur bahwa karena mereka terburu-buru untuk menyelesaikan tulisan mereka saat proses penulisan di dalam kelas berlangsung. Dan juga, mungkin disebabkan keterbatasan waktu yang diberikan ketika mereka menulis teks prosedur dalam kelas. Mereka harus direvisi dan selesai menulis selama 120 menit. Dan tulisan mereka akan dievaluasi berdasarkan proses yang menulis, fitur organisasi, fitur bahasa, dan kejelasan tulisan. Jadi, sebelum mahasiswa disampaikan hasil tulisan mereka, mereka harus mengevaluasi tulisan mereka sendiri untuk mendapatkan hasil yang memuaskan. Namun sayangnya, hasil menulis beberapa mahasiswa ditemukan hasil tak terduga yang dapat dilihat pada draft pertama yang disampaikan kepada peneliti. Di sini, Sanu (2013) yang melakukan penelitian untuk mahasiswa di tingkat universitas mengenai proses penulisan, ia melaporkan bahwa waktu yang diberikan (120 menit) tidak cukup untuk mahasiswa untuk memproses dan menyelesaikan tulisan mereka di dalam kelas. Ini berarti bahwa dengan memberikan banyak waktu atau waktu tambahan, diharapkan bahwa mahasiswa dapat dapat menyelesaikan tulisan mereka berhasil dan memuaskan. Memang, mereka tidak akan merasa terburu-buru untuk menyelesaikan tulisan mereka.

Berikutnya, sebagaimana dinyatakan di atas bahwa ada perbaikan dari produk menulis mahasiswa dinilai melalui portofolio. Penilaian ini difokuskan pada aspek proses penulisan, fitur organisasi, fitur bahasa dan kejelasan tulisan. Berdasarkan temuan data yang telah disajikan di atas, menunjukkan bahwa ada perbedaan penulisan mahasiswa prosedur teks antara draft pertama dan draft akhir untuk setiap topik. Hal ini dapat dilihat bahwa aspek proses penulisan ditulis oleh mahasiswa yang ditemukan dalam draft pertama, ada beberapa mahasiswa menulis proses penulisan di mana tujuannya, bahan / material, langkah dan evaluasi harus dijelaskan tertib dan benar, tetapi mahasiswa tidak menulis aspek ini secara efektif. Kombinasi tujuan, bahan, langkah-langkah, dan evaluasi tidak dijelaskan lebih rinci. Tapi setelah memberikan umpan balik melalui penilaian portofolio, hasil tulisan mahasiswa yang dapat ditemukan dalam draft akhir untuk setiap topik, aspek proses penulisan telah dikenal sangat baik dan dijelaskan tertib. Memang, cara-cara membuat sesuatu yang akan disampaikan dapat dikomunikasikan secara berarti. Hal itu menunjukkan bahwa menilai 
mahasiswa produk menulis melalui portofolio berpengaruh perbaikan pada mahasiswa 'pengetahuan dalam menulis teks prosedur.

Selain itu, peneliti menemukan beberapa kesalahan pada aspek fitur organisasi yang dibuat oleh mahasiswa. Dari analisis data, para mahasiswa tidak menggabungkan dan mengatur hukuman mereka secara sistematis. Kemudian, mereka membuat kesalahan dalam membuat kalimat yang baik. Di sini, Matthews (1981) mengatakan kalimat adalah serangkaian kata-kata dalam pidato terhubung atau menulis, membentuk ekspresi tata bahasa lengkap satu pikiran. Ini berarti bahwa kalimat yang baik dapat dibangun jika penulis dapat menggabungkan kata-kata untuk menjadi frase yang baik atau kalimat gramatikal untuk mengekspresikan ide. Sudah jelas bahwa dengan menguasai tata bahasa, itu akan mempengaruhi pengetahuan mahasiswa dalam membangun kalimat yang baik. Sayangnya, peneliti juga mengidentifikasi mahasiswa memiliki masalah pada aspek fitur bahasa. Hal ini dapat dilihat bahwa dari hasil tulisan mahasiswa yang telah disajikan dalam temuan di atas, menunjukkan bahwa beberapa kesalahan dari fitur bahasa seperti tegang, kesepakatan, bentuk kata kerja, kata ganti, kata depan, jumlah, urutan kata, dan artikel ditemukan pada produk menulis mahasiswa. Dan juga, beberapa kesalahan pada aspek kejelasan tulisan ejaan seperti, tanda baca, huruf kapital, dan pilihan kata juga ditemukan pada tulisan mahasiswa. Temuan kesalahan ini dibuat oleh mahasiswa, itu mirip dengan temuan Msanjila (2005) yang menyelidiki masalah mahasiswa dalam keterampilan menulis. Dia melaporkan bahwa ada enam mencolok dari masalah penulisan yang dihadapi oleh mahasiswa. Mereka kapitalisasi dan tanda baca masalah, inexplicitness atau ketidakjelasan, organisasi miskin atau urutan logis, masalah ejaan dan kesalahan tata bahasa.
Melihat kesalahan yang ditemukan pada hasil tulisan mereka dalam draft pertama, kesalahan-kesalahan belum ditemukan dalam draft akhir untuk setiap topik setelah peneliti menilai mahasiswa menulis dalam draft pertama menggunakan portofolio. Oleh karena itu, aspek proses penulisan yang diuraikan di mengintegrasikan tujuan, bahan / material, langkah / prosedur, dan evaluasi telah ditulis secara sistematis. Dan juga, fitur organisasi, fitur bahasa, dan kejelasan tulisan telah dipecahkan kesalahan yang oleh mahasiswa. Hal ini dapat dilihat dari draft akhir untuk setiap topik adalah lebih baik daripada draft pertama. Draft final jelas dan lebih rinci untuk menjelaskan bagaimana membuat dan menangani sesuatu berdasarkan tujuan dari topik yang diberikan. Singkatnya, ada perbaikan dari mahasiswa pengetahuan dalam menulis teks prosedur setelah menilai mahasiswa produk menulis menggunakan portofolio. Dapat dikatakan bahwa penilaian portofolio memberi hasil yang lebih baik untuk meningkatkan keterampilan mahasiswa dalam menulis teks prosedur. Perkembangan ini bisa sukses dilaksanakan karena ketika peneliti menilai mahasiswa menulis, ia merevisi mahasiswa karya, memberikan umpan balik, dan dikoreksi kesalahan mahasiswa. Selain itu, peneliti juga meminta mahasiswa untuk merevisi tulisan mereka berdasarkan draft sebelumnya yang telah dikoreksi oleh peneliti. Dengan memberikan kebenaran, para mahasiswa dapat dapat belajar secara tertulis teks prosedur dari kesalahan mereka. Selanjutnya, mereka dapat belajar apa yang salah atau benar dengan komposisi mereka menulis teks prosedur. Selain itu, melalui portofolio, peneliti sebagai kuliah mereka dapat mengetahui kemajuan belajar mahasiswa, untuk mendiagnosa kesulitan mereka dalam menulis teks prosedur, dan memberikan umpan balik untuk proses pembelajaran yang lebih baik. Jadi, peneliti dapat diatur dan disiapkan bahan berikutnya penulisan 
pengajaran untuk murid-muridnya. Melihat mahasiswa kemajuan dalam menulis prosedur teks yang telah dijelaskan di atas, terbukti dengan Weinbaum (1991) yang menyatakan bahwa penilaian portofolio dapat mendorong mahasiswa keterlibatan dan perbaikan dalam proses belajar mereka. Lebih lanjut ia menambahkan bahwa melalui penilaian portofolio, para mahasiswa dapat memantau kemajuan mereka sejak guru mereka telah diberi umpan balik dari apa yang mereka telah dilakukan. Dalam hal ini, peningkatan kemajuan mahasiswa dalam menulis teks prosedur jelas menunjukkan membandingkan dengan draft pertama.

\section{Kesimpulan}

Berdasarkan analisis dan interpretasi temuan penelitian ini, peneliti ingin menyimpulkan penelitian ini sebagai berikut:

1. Ada empat struktur prosedur teks yang ditulis oleh mahasiswa semester ketiga dari Politeknik Negeri Balikpapan. Mereka tujuan, bahan / material, langkah / prosedur, dan evaluasi.

2. Ada peningkatan produk menulis siswa setelah menilai melalui penilaian portofolio. Hal ini dapat dibandingkan dari menulis siswa antara draft pertama dan draft akhir untuk setiap topik yang diberikan di mana aspek proses penulisan, fitur organisasi, fitur bahasa dan kejelasan tulisan yang ditemukan dalam draft akhir ini telah dinyatakan dan diuraikan secara efektif dan bermakna dari draft pertama ditulis oleh siswa..

\section{Saran}

Diperlukan adanya penelitian lebih lanjut mengenai penilaian portfolio dengan berbagai metoda ajar dan berbagai materi sehingga akan menghasilkan produk pembelajaran yang maksimal

\section{Daftar Pustaka}

Anderson, Mark and Kathy Anderson.1997. Text Types in English 1.
South Yarra: Machmillan Education Malaysia.

Crookes. P, and Davies. S. 1998. Research into Practice: Essential Skills for Reading and Applying Research. London: Ballière Tindall, in association with the RCN.

Derewianka, Baverly. Exploring how texts work. Australia: Primary English Teaching Association.

Feez, Susan \& Joyce, Helen. 1998. Writing Skills: Narrative \& Non-Fiction Text Types. Australia: Phoenix Education.

Grace. C., \& E.F. Shores. 1992. The Portfolio and Its Uses: Developmentally Appropriate Assessment of Young Children. Little Rock. AR: Southern Association on Children Under Six.

Hall, Shane. 2013. How To Do Content Analysis. [Online] available at http://classroom.synonym.com/contentanalysis-2670.html (Retrieved on June, 2013)

Jolly, David. 1993. Writing Task: An authentic-task approach to individual writing needs. New York: Cambridge University Press.

Matthews, P.H. 1981. Syntax. New York: Cambridge University Press.

Msanjila, Yohana P. 2005. Problems of writing in Kiswahili: Case study of Kigurunyembe and Morogor Secondary Schools in Tanzania. Nordic Journal of African Studies, Vol. 14(1), p: 15-25.

O'Malley, J. M., \& Pierce, L. V. 1996. Authentic Assessment for English Language Learners. Reading, MA: Addison-Wesley.

Oshima, A. and Hogue, A. 1997. Introduction to Academic Writing. New York: Addison-Wesley Longman Publishing Company. 
Polit D.F., Hungler B.P. 1999. Nursing Research: Principles and Methods (6th Ed.). Philadelphia: Lippincott.

Sanu, La Ode. 2013. Investigating the problems of comparison and contrast essay of EFL students of State Institute of Islamic Studies (STAIN) Samarinda. Unpublished Graduated School Thesis. Samarinda: Unmul.
Self, J. (n.d.). Virginia's Literacy Passport Test (LPT) for Writing: A Performance Assessment. A Resource Notebook for Teachers. Radford, Va: Virginia Department of Education, Regional Field Services, Radford University.

Setiawan, Otong Djuharie.2008. Genre. Bandung: CV.Yrama Widya.

Weinbaum, Kerry. 1991. Portfolio as a vehicle for student empowerment and teacher change in portfolios: Process and Product. Belanoff, P and Dickson, M.(Ed). USA: Boynton/Cook Publisher Inc. 